\title{
RANCANGAN LEAN PRODUCTION DENGAN MENGGUNAKAN VALUE STREAM ANALYSIS TOOLS (VALSAT) UNTUK ELIMINASI WASTE DOMINAN \& MENINGKATKAN PRODUKTIVITAS SISTEM PRODUKSI Studi Kasus: CV. Sogan Batik Rejodani
}

\author{
Dhuha Khanif Rizky ${ }^{1}$, M. Ridwan Andi Purnomo ${ }^{2}$, Nashrullah Setiawan ${ }^{3}$ \\ Jurusan Teknik Industri, Fakultas Teknologi Industri, Universitas Islam Indonesia ${ }^{1,2,3)}$ \\ Jalan Kaliurang Km. 14,5 Sleman, Yogyakarta 55501 \\ E-mail:dhuhanifr@gmail.com,ridwan_ie@uii.ac.id,nashurallah.setiawan@uii.ac.id
}

\begin{abstract}
With increasing competition in the industry, SMEs are required to be able to do continuous improvement to improve its performance so as to compete with other SMEs and able to apply the concept of lean production. In CV SBR, demand will increase in Ramadan. With the increase in orders, then the CV SBR required to continue to meet customer demand in a timely manner in accordance consumer expectations. This research will try to apply the concept of lean production by using value stream mapping and analysis of waste using the Value Stream Analysis Tools (VALSAT) in order to increase the productivity of the production system in the CV Sogan Batik Rejodani. The purpose of this study is to determine the percentage of Value Added, Non-Value Added, and Necessary but Non-Value Added Activity of batik production system. Furthermore, to determine the design of future state value stream mapping in CV SBR. Obtained results are given in the form of proposed improvements that can reduce the Non-Value Added Activity from $43 \%$ to $13 \%$. In addition the draft future state value stream mapping can reduce cycle time from 16115.88 seconds to 15062.96 seconds and can reduce the lead time from 24589,028 seconds to 15932.62 seconds. With the reduction in value-added activity, it can increase the output of the product in a day so that the productivity of the production system increases.
\end{abstract}

Keywords : Lean Production, Productivity, Waste, Value Stream Mapping.

\section{PENDAHULUAN}

Dengan semakin ketatnya persaingan di dunia industri, UKM dituntut untuk mampu melakukan perbaikan secara terus-menerus (continous improvement) untuk meningkatkan kinerjanya sehingga mampu bersaing dengan UKM lain dan mampu menerapkan konsep lean production. Dalam mewujudkan konsep lean production, perlu dilakukan analisis dan pengamatan untuk memperbaiki sistem produksi sehingga dapat mengurangi waste yang menyebabkan pemborosan bahkan kerugian terhadap perusahaan. Sehingga dengan berkurangnya waste maka diharapkan dapat meningkatkan produktivitas sistem produksi.

Pendekatan yang dilakukan dalam upaya mengurangi waste dan meningkatkan produktivitas sistem produksi adalah konsep lean production. Konsep lean productionyaitu merupakan sebuah konsep merampingkan proses produksi sehingga waste yang dihasilkan dapat dikurangi dan produktivitas dapat semakin ditingkatkan.

Pada CV Sogan Batik Rejodani, permintaan akan meningkat pada bulan Ramadan diakibatkan oleh konsumen ingin menggunakan baju muslim dengan corak batik pada saat Ramadan dan Idul Fitri. Dengan meningkatnya pesanan, maka CV Sogan Batik dituntut untuk tetap dapat memenuhi permintaan konsumen secara tepat waktu sesuai harapan konsumen. Bulan Ramadan tahun ini terjadi pada bulan JuniJuli sehingga permintaan akan meningkat pada bulan Mei, data permintaan seluruh produk pada bulan Januari - Juni 2016 dapat dilihat pada gambar 1 berikut : 


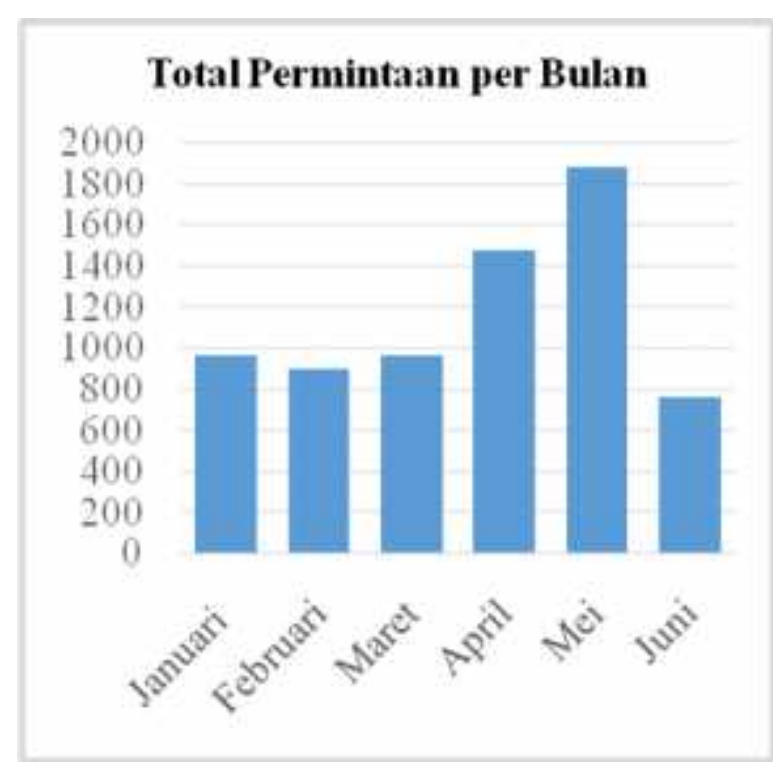

Gambar 1.Grafik Total Permintaan Januari-Juni 2016.

(Sogan Batik, 2016)

Permasalahan tersebut dapat diselesaikan dengan mengurangi lead time produksi karena berdasarkan Hines \& Taylor (2000), $60 \%$ total lead time pada proses produksi merupakan non value added yang dapat dikurangi untuk meningkatkan produktivitas, $35 \%$ merupakan necessary but non value added dan 5\% merupakan value added activity. Maka metode yang tepat dalam mengurangi lead time yaitu dengan menggunakan Value Stream Mapping (VSM).

Kelebihan VSM salah satunya yaitu dapat mengurangi lead time secara signifikan, dibuktikan oleh penelitian yang dilakukan oleh Choomlucksanaet al. (2015), hasilnya ternyata proses pemolesan pada industri lembaran metal merupakan penyebab terbanyak aktivitas non-value added dan perlu segera ditangani. Setelah diperbaiki, proses pemolesan berkurang dari 6582 detik menjadi 2468 detik atau sebanyak 62,5\%. Selain itu aktivitas non - value added berkurang dari 1086 aktivitas menjadi 261 aktivitas, atau sebanyak 66,53\%. Selain itu biaya yang dikeluarkan berkurang menjadi 1764 Dollar per tahun.

Pada penelitian ini akan mencoba mengaplikasikan konsep lean production dengan menggunakan value stream mapping dan analisis waste menggunakan Value
Stream Analysis Tools (VALSAT) guna meningkatkan produktivitas sistem produksi pada CV Sogan Batik Rejodani. Tujuan yang ingin dicapai yaitu mengetahui persentase Value Added, Non-Value Added, dan NecessarybutNon-Value AddedActivity dari sistem produksi batik pada UKM Sogan Batik Rejodani. Setelah melakukan eliminasi waste maka dilakukan rancangansistem produksi yang baru menggunakan future state value stream mapping (FSVSM).

\section{METODE PENELITIAN}

Penelitian yang dilakukan ini memiliki tujuan untuk mengetahui prosentase Value Added, Non-Value Added, dan Necessary but Non-Value Added Activity dari sistem produksi batik pada UKM Sogan Batik Rejodani. Selain itu untuk mengetahui desain future state value stream mapping pada UKM Sogan Batik Rejodani.Langkahlangkah yang perlu dilakukan adalah sebagai berikut :

1. Identifikasi masalah melalui observasi, wawancara, dan pengumpulan data yang dibutuhkan.

2. Perhitungan waktu siklus dan lead time.

3. Penyusunan current state value stream mapping.

4. Pengumpulan data untuk menentukan pembobotan kuesioner 7 pemborosan.

5. Wawancara dengan expert untuk identifikasi waste menggunakan kuesioner 7 pemborosan.

6. Penentuan detailed mapping tools VALSAT berdasarkan hasil kuesioner 7 pemborosan.

7. Analisis waste dengan detailed mapping tools terpilih.

8. Analisis waste menggunakan diagram fishbone.

9. Penyusunan rancangan perbaikan menggunakan future state value stream mapping. 


\section{HASIL DAN PEMBAHASAN}

\subsection{Identifikasi Masalah}

Penelitian dilakukan berdasarkan prinsip continous improvement, dimana tidak ada kondisi yang terbaik tetapi selalu ada kondisi yang lebih baik. Dengan prinsip ini maka perlu dilakukan perbaikan secara terus menerus dengan harapan akan menjadi lebih baik lagi. Pada kasus Sogan Batik Rejodani maka kondisi proses produksi yang sudah ada akan dianalisis dan dicari rekomendasi perbaikan untuk meningkatkan produktivitas sistem produksi. Identifikasi dilakukan berdasarkan observasi di lapangan dan berdasarkan pada kondisi saat ini.

\subsubsection{Pembuatan Current State Value Stream Mapping}

Langkah - langkah yang perlu dilakukan dalam menyusun value stream mapping yaitu sebagai berikut :

1. Memahami aliran material dan informasi.

2. Memahami proses produksi.

3. Menemukan permasalahan.

4. Melakukan perbaikan.

Pengumpulan data dilakukan dengan menggunakan data waktu siklus yang diambil menggunakan metode stopwatch time study dengan pengambilan waktu secara acak sebanyak 35 kali.

Tabel 1 berikut ini adalah data jumlah operator masing - masing stasiun kerja pada proses produksi Syahla.01 Abaya :

Tabel 1 Operator Stasiun Kerja

\begin{tabular}{|c|l|c|}
\hline No & \multicolumn{1}{|c|}{ Stasiun Kerja } & $\begin{array}{c}\text { Jumlah } \\
\text { Operator }\end{array}$ \\
\hline 1 & Pewarnaan & 3 \\
2 & Pemilihan Kain dan & 1 \\
3 & Pra Potong & 9 \\
4 & Pemotongan & 16 \\
5 & Penjahitan & 2 \\
6 & Quality Control & 2 \\
7 & Femasangan Kancing & 2 \\
8 & Packaging dan & 2 \\
\hline
\end{tabular}

Tabel 2.berikut ini adalah data available time masing - masing stasiun kerja pada proses produksi Syahla.01 Abaya :

Tabel 2 Available Time

\begin{tabular}{|c|l|c|}
\hline No & \multicolumn{1}{|c|}{ Stasiun Kerja } & $\begin{array}{c}\text { Waktu } \\
\text { (detik) }\end{array}$ \\
\hline 1 & Pewarnaan & 25200 \\
2 & Pemilihan Kain dan & 25200 \\
3 & Pra Potong & 25200 \\
4 & Pemotongan & 25200 \\
5 & Penjahitan & 25200 \\
6 & Quality Control & 25200 \\
7 & Femasangan Kancing & 25200 \\
8 & Packaging dan & 25200 \\
\hline
\end{tabular}

Tabel 3 berikut ini adalah data total lead time dan cycle time pada proses produksi Syahla.01 Abaya :

Tabel 3 Total Waktu

\begin{tabular}{|c|l|c|}
\hline No & \multicolumn{1}{|c|}{ Keterangan } & $\begin{array}{c}\text { Jumlah Waktu } \\
\text { (detik) }\end{array}$ \\
\hline 1 & Total Lead Time & 24589,028 \\
2 & Total Cycle Time & 16115,88 \\
\hline
\end{tabular}

Setelah didapatkan data - data yang mendukung dalam penyusunan value stream mapping, langkah selanjutnya yaitu menyusun current state value stream mapping untuk proses produksi Syahla.01 Abaya. Current state value stream mapping di lampirkan pada lampiran 1.

\subsubsection{Analisa Current State Value Stream Mapping}

Dalam mendesain CSVSM maka mempertimbangkan jumlah operator, cycle time, lead time, uptime, dan available time. Dalam menyusun CSVSM juga perlu mengetahui proses bisnis secara keseluruhan. Dari hasil penyusunan CSVSM diketahui total cycle time yaitu sebesar 16115.88 detik. Sedangkan total lead time yaitu sebesar 24589.028 detik. Dengan kata lain, dibutuhkan waktu sekitar 6.84 jam untuk 
memproduksi satu produk Syahla.01 Abaya pada CV Sogan Batik Rejodani.

\subsection{Identifikasi dan Pengukuran Waste}

Kuisioner diberikan kepada pihak manajer produksi CV Sogan Batik Rejodani. Hal ini dilakukan karena manajer yang paling memahami proses produksi Syahla.01 Abaya. Selanjutnya peneliti juga melakukan validasi dengan melihat kondisi di lapangan. Pembobotan yang digunakan yaitu menggunakan skala 1 sampai dengan 5 dengan pembobotan yang telah disesuaikan dengan kondisi proses produksi Syahla.01 Abaya di CV Sogan Batik Rejodani. Hasil dari kuisioner tersebut dijelaskan pada tabel 4.berikut :

Tabel 4 Rekapitulasi

Kuisioner 7 Pemborosan

\begin{tabular}{|c|l|c|c|c|}
\hline No & Pemborosan & Skor & Rank & Bobot \\
\hline 1 & Over production & 0 & 6 & $0 \%$ \\
2 & Defect & 3 & 1 & $30 \%$ \\
3 & $\begin{array}{l}\text { Unnecessary } \\
\text { Inventory } \\
4\end{array}$ & 0 & 6 & $0 \%$ \\
& $\begin{array}{l}\text { Inapproriate } \\
5\end{array}$ & 2 & 2 & $20 \%$ \\
6 & $\begin{array}{l}\text { Processing } \\
\text { Excessive }\end{array}$ & 1 & 5 & $10 \%$ \\
7 & $\begin{array}{l}\text { Transportation } \\
\text { Waiting }\end{array}$ & 2 & 2 & $20 \%$ \\
\hline & Unnecessary & 2 & 2 & $20 \%$ \\
\hline & Totion & $\mathbf{1 0}$ & & $\mathbf{1 0 0 \%}$ \\
\hline
\end{tabular}

\subsubsection{Analisa Hasil Kuesioner}

Dari rekapitulasi hasil kuisioner 7 pemborosan tersebut, dapat diketahui bahwa terdapat beberapa waste yang terjadi. Berikut ini merupakan analisa terhadap waste yang terjadi pada proses produksi Syahla.01 Abaya :

\section{Overproduction}

Hasil skor dari overproduction yaitu 0 yang artinya sisa $0-50$ unit dalam 1 bulan. Hal ini dapat terjadi karena sistem yang dilakukan CV Sogan Batik Rejodani yaitu make-to-order dimana produk yang dibuat hanya sesuai pesanan. Selain itu bahan baku yang dipesan juga sudah disesuaikan dengan produk yang akan diproduksi.

\section{Defect}

Hasil skor dari jenis waste defect yaitu 3 yang artinya defect terjadi sebanyak 7\% - 8\% dalam 1 bulan. Jenis waste defect merupakan waste terbanyak dengan bobot 30\%. Defect yang banyak terjadi yaitu di proses pemotongan, penjahitan, dan pewarnaan. Dimana pada proses pemotongan banyak terjadi salah potong, pada proses penjahitan terjadi hasil jahitan yang miring atau melebihi batas, dan pada proses pewarnaan banyak ditemui kain yang hasil warnanya tidak merata. Hal ini dapat diakibatkan oleh kurang telitinya operator dalam menjalankan tugasnya, selain itu dapat diakibatkan oleh stasiun kerja yang kurang mendukung.

\section{Unnecessary Inventory}

Hasil skor pada jenis waste unnecessary inventory yaitu 0 yang artinya masa simpan di dalam gudang kurang dari 7 hari. Hal ini dikarenakan CV Sogan Batik Rejodani sudah menerapkan reorder point dan safety stock dengan cukup baik. Selain itu juga dilakukan forecasting secara kualitatif pada saat saat tertentu seperti pada musim hari raya lebaran.

\section{Inapproriate Processing}

Hasil skor pada jenis waste innapproriate processing yaitu 2 yang artinya terjadi 21 30 aktivitas tidak perlu dalam satu kali proses produksi. Hal ini terjadi dikarenakan belum adanya standar operasional prosedur yang diterapkan oleh CV Sogan Batik Rejodani. Tidak adanya SOP ini menimbulkan efek pada produk cacat seperti warna kain yang tidak merata, hasil jahit melebihi batas atau miring, dan hasil pemotongan terjadi salah potong.

\section{Excessive Transportation}

Hasil skor pada jenis waste excessive transportation yaitu 1 yang artinya total jarak dalam satu kali proses produksi sekitar 51 - 100 meter. Hal ini terjadi dikarenakan penataan tata letak fasilitas yang ada pada proses produksi tidak urut sesuai flow proses produksi sehingga terjadi banyak perpindahan bahan baku walaupun belum mengganggu proses produksi. 


\section{6. $\quad$ Waiting}

Hasil skor pada jenis waste waiting yaitu 2 yang artinya terjadi waktu menunggu selama 61 - 120 detik dalam satu kali proses produksi. Hal ini dapat terjadi dikarenakan banyak proses yang perlu menunggu cukup lama sebelum dapat dikerjakan diantaranya yaitu proses penjemuran dan perendaman. Selain itu operator bisa menganggur apabila tidak terdapat banyak pesanan pada hari tersebut.

\section{Unnecessary Motion}

Hasil skor pada jenis waste unnecessary motion yaitu 2 yang artinya terjadi gerakan tidak perlu sebanyak 21 - 30 gerakan dalam satu kali proses produksi. Hal tersebut terjadi dikarenakan operator masih banyak melakukan gerakan yang tidak perlu. Selain itu juga banyak terjadi operator yang kurang disiplin dalam bekerja sehingga masih banyak melakukan kegiatan diluar pekerjaan utama.

\subsection{Pemilihan Tools VALSAT}

Perhitungannya yaitu dengan mengalikan hasil skor pada kuisioner 7 pemborosan dengan bobot dari masing-masing tools yang ada. Hasil perhitungan VALSAT akan dijelaskan pada lampiran 2 .

Setelah diketahui bobot dari masing masing tool yang ada, maka langkah selanjutnya yaitu mengurutkan dari yang tertinggi ke yang terendah. Tool dengan bobot tertinggi maka merupakan tool yang terpilih untuk mengidentifikasi waste yang ada pada proses produksi Syahla.01 Abaya di CV Sogan Batik Rejodani. Tabel 5 berikut merupakan rekapitulasi hasil VALSAT :

\section{Tabel 5 Rekapitulasi Hasil VALSAT}

\begin{tabular}{|c|c|c|c|}
\hline No & Detailed Mapping Tools & Skor & Ranking \\
\hline 1 & PAM & 66 & 1 \\
2 & SCRM & 20 & 3 \\
3 & PVF & 8 & 4 \\
4 & QAM & 29 & 2 \\
5 & DA & 6 & 6 \\
6 & DPA & 8 & 4 \\
7 & PS & 1 & 7 \\
\hline
\end{tabular}

Dari hasil tersebut dapat diketahui bahwa skor paling tinggi yaitu PAM dengan total skor 66. Maka tool yang dipilih adalah PAM (Process Activity Mapping). Tool ini sering di gunakan oleh ahli teknik industry untuk memetakan keseluruhan aktivitas secara detail guna mengeliminasi waste, ke tidak konsistenan, dan ke irasionalan di tempat terjadi sehingga tujuan meningkatkan kualitas produk dan memudahkan layanan, mempercepat proses dan mereduksi biaya diharapkan dapat terwujud (Hines \& Rich, 1997). Langkah selanjutnya yaitu membuat perhitungan Process Activity Mapping yang dapat dilihat pada lampiran 3.

\subsubsection{Analisa Process Activity Mapping}

Processactivity mapping akan memberikan gambaran aliran fisik dan informasi,waktu yang diperlukan untuk setiap aktivitas, jarak yang ditempuh dan tingkat persediaan produk dalam setiap tahap produksi. Kemudahan identifikasi aktivitas terjadi karena adanya penggolongan aktivitas menjadi lima jenis yaitu operasi, transportasi, inspeksi, delay dan penyimpanan. Operasi dan inspeksi adalah aktivitas yang bernilai tambah.Sedangkan transportasi dan penyimpanan berjenis penting tetapi tidak bernilai tambah. Adapun delay adalah aktivitas yang dihindari untuk kerja disehingga merupakan aktivitas berjenis tidak bernilai tambah. (Hines \& Rich, 1997).

Dilakukan pengelompokan aktivitas mana saja yang termasuk operasi, transportasi, inspeksi, storage, dan delay. Selanjutnya mengelompokkan aktivitas mana saja yang termasuk value added activity, non-value added activity, dan necessary but non-value added activity. Hasil rekapitulasi total waktu PAM dapat dilihat pada tabel 6. 
Tabel 6 Total Waktu

\begin{tabular}{|l|c|c|c|c|}
\hline \multicolumn{1}{|c|}{ Aktivitas } & Jumlah & Total Waktu (detik) & Total Waktu (jam) & Prosentase \\
\hline Operasi & 20 & 12416,28 & 3,45 & $50 \%$ \\
Transportasi & 7 & 221,96 & 0,06 & $1 \%$ \\
Inspeksi & 5 & 970,61 & 0,27 & $5 \%$ \\
Storage & 6 & 292,18 & 0,08 & $1 \%$ \\
Delay & 21 & 10688,00 & 2,97 & $43 \%$ \\
VA & 25 & 13386,89 & 3,72 & $54 \%$ \\
NVA & 21 & 10688,00 & 2,97 & $43 \%$ \\
NNVA & 13 & 514,14 & 0,14 & $3 \%$ \\
\hline
\end{tabular}

Operasi dan inspeksi adalah aktivitas yang bernilai tambah. Sedangkan transportasi dan penyimpanan berjenis penting tetapi tidak bernilai tambah. Adapun delay adalah aktivitas yang di hindari untuk terjadi sehingga merupakan aktivitas berjenis tidak bernilai tambah. Dapat dilihat bahwa aktivitas tertinggi yaitu pada operasi sebanyak 50\%, disusul selanjutnya oleh delay dengan $43 \%$, dan sisanya yaitu inspeksi dengan 5\%, storage dan transportasi dengan masingmasing $1 \%$. Selanjutnya dapat dilihat bahwa aktivitas bernilai tambah dengan 54\%, tidak bernilai tambah dengan $43 \%$, dan penting tetapi tidak bernilai tambah dengan $3 \%$.

Berdasarkan prinsip waste reduction, maka aktivitas - aktivitas yang termasuk kedalam aktivitas tidak penting perlu direduksi untuk meningkatkan produktivitas sistem produksi Syahla.01 Abaya. Hasil analisis detailed mapping tools ini dapat digunakan sebagai dasar dalam melakukan perbaikan yang akan di usulkan.

\subsection{Identifikasi Akar Penyebab Waste}

Dalam mempermudah dalam melakukan analisis, maka dibuatlah sebuah diagram fishbone untuk jenis waste yang paling tinggi yaitu jenis defect. Analisis terhadap fishbone diagram dilakukan dengan mempertimbangkan 4 faktor yaitu Man, Method, Machine, dan Material. Hasil analisis dengan menggunakan diagram fishbone yaitu dapat dilihat pada gambar 5.1 berikut :

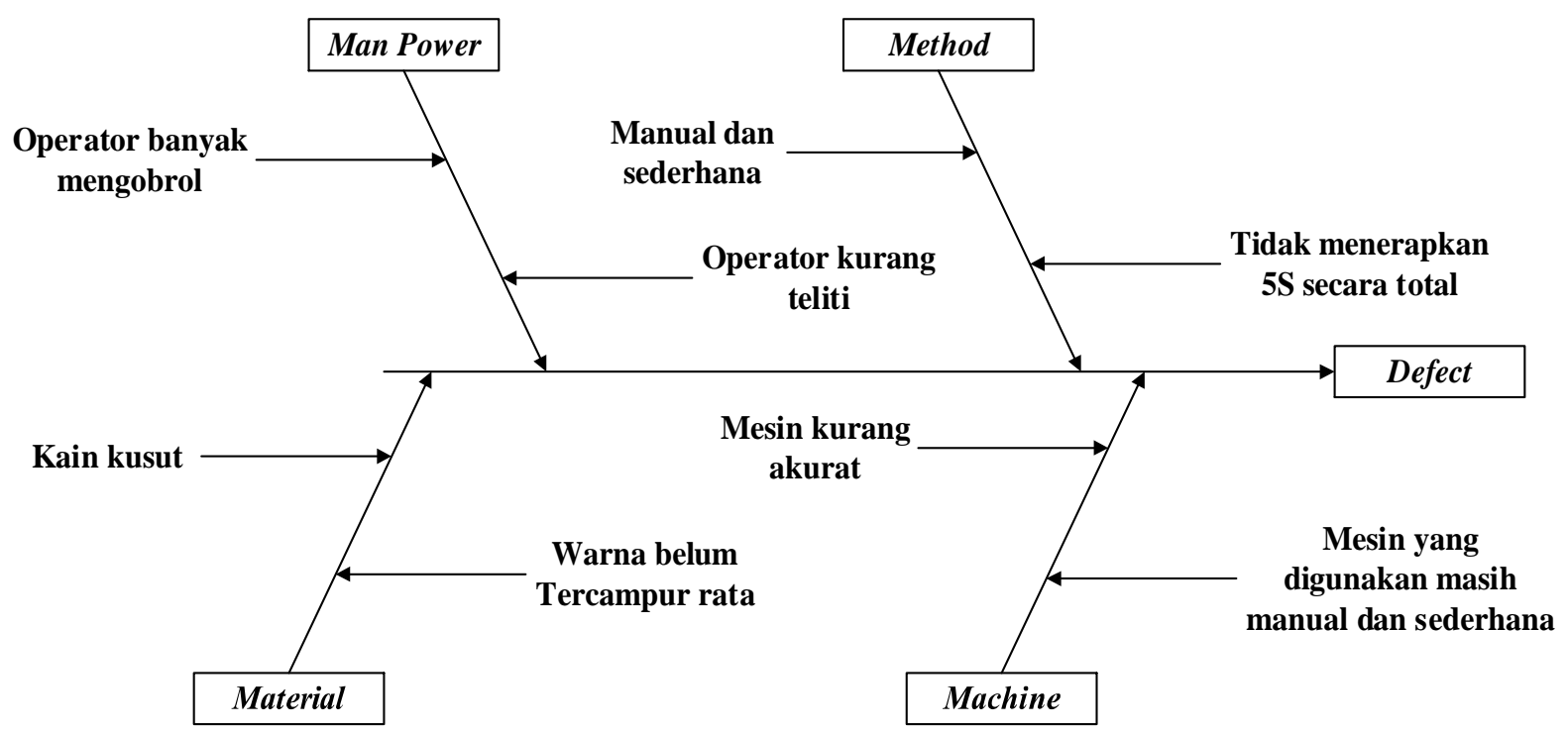

Gambar 2. Diagram Fishbone Jenis Defect. 
Dapat dilihat bahwa pada faktor mesin ditemukan bahwa mesin yang digunakan masih manual dan sederhana yang mengakibatkan mesin kurang akurat dalam memberikan hasil pekerjaannya. Pada faktor metode ditemukan bahwa masih dilakukan secara manual dan sederhana, selain itu CV Sogan Batik Rejodani belum menerapkan 5S secara menyeluruh. Pada faktor material ditemukan bahwa warna yang belum tercampur rata dan kain yang kusut dapat menyebabkan defect. Pada faktor manusia ditemukan bahwa operator masih banyak mengobrol sehingga operator kurang teliti dalam mengerjakan pekerjaannya.

\subsection{Rekomendasi Perbaikan}

Rekomendasi perbaikan yang diberikan yaitu berdasarkan waste yang paling berpengaruh dan berdasarkan hasil VALSAT. Berdasarkan hasil wawancara dan analisis, defect yang terjadi yaitu di stasiun pewarnaan, pemotongan, dan penjahitan. Dimana pada proses pemotongan banyak terjadi salah potong, pada proses penjahitan terjadi hasil jahitan yang miring atau melebihi batas, dan pada proses pewarnaan banyak ditemui kain yang hasil warnanya tidak merata. Sehingga rekomendasi yang dapat diberikan untuk mengurangi leadtime diantaranya yaitu :

1. Membeli mesin pengering untuk mengeringkan kain setelah proses pewarnaan.

2. Membeli mesin potong sehingga tidak terjadi salah potong dan lebih akurat.

3. Menerapkan 5S secara total dan melibatkan seluruh elemen yang ada di UKM.
4. Mengisi buku borongan yang awalnya dibebankan kepada operator diganti menjadi tugas admin produksi.

5. Membuat SOP sehingga terdapat standar kerja yang baku yang dapat diterapkan oleh semua pihak.

\subsection{Penyusunan Future State Value Stream Mapping}

Usulan perbaikan yang telah diberikan sebelumnya kemudian di jadikan dasar dan patokan dalam memberikan usulan berdasarkan process activity mapping. Bentuk usulan perbaikan berdasarkan PAM yaitu dengan mengurangi waktu siklus pada beberapa aktivitas - aktivitas tidak bernilai tambah. Aktivitas yang dikurangi yaitu aktivitas - aktivitas bertipe delay dan transportasi karena dirasa tidak terjadi masalah pada aktivitas-aktivitas bertipe inspeksi, storage, dan operasi.

Beberapa aktivitas yang dikurangi diantaranya yaitu aktivitas penjemuran kain yang sangat tergantung pada kondisi cuaca. Hal ini dapat diatasi dengan membeli mesin pengering yang lebih cepat dan efisien. Halhal seperti menyiapkan gunting dan pola, membuang air sisa, transfer ke lokasi penjemuran, ambil barang, dan ambil aksesoris merupakan aktivitas - aktivitas yang tidak perlu dilakukan dan dapat dihilangkan. Selanjutnya pada aktivitas mengisi buku borongan pada aktivitas pemotongan dan penjahitan dapat dihilangkan dengan menggunakan kartu kanban atau dengan mengganti tugas mengisi buku borongan menjadi tugas admin produksi, bukan operator. Data perbaikan waktu dapat dilihat pada tabel 7 berikut :

Tabel 7 Perbaikan Jumlah Waktu PAM

\begin{tabular}{|l|c|c|c|c|}
\hline \multicolumn{1}{|c|}{ Aktivitas } & $\Sigma$ & Total Waktu (detik) & Total Waktu (jam) & Prosentase \\
\hline Operasi & 20 & 12416.28 & 3.448968016 & $78 \%$ \\
Transportasi & 6 & 167.42 & 0.046506032 & $1 \%$ \\
Inspeksi & 5 & 970.61 & 0.269612698 & $6 \%$ \\
Storage & 6 & 292.18 & 0.081160635 & $2 \%$ \\
Delay & 8 & 2076.12 & 0.57670127 & $13 \%$ \\
VA & 25 & 13386.89 & 3.718580714 & $84 \%$ \\
NVA & 8 & 2076.12 & 0.57670127 & $13 \%$ \\
NNVA & 12 & 459.60 & 0.127666667 & $3 \%$ \\
\hline
\end{tabular}


Perubahan yang terjadi di antaranya yaitu jumlah aktivitas pada transportasi turun dari 7 menjadi 6 dengan total waktu dari 221.96 detik menjadi 167.42 detik. Selanjutnya pada jumlah aktivitas delay yang turun dari 21 menjadi 8 dengan total waktu dari 10688.00 detik menjadi 2076.12 detik. Dari pengurangan waktu tersebut, maka total waktu produksi berubah dari 24589.028 detik menjadi 15922.615 detik. Terdapat banyak aktivitas delay yang dihilangkan karena aktivitas - aktivitas tersebut dapat diperbaiki dengan menggunakan saran saran yang telah diberikan berdasarkan analisis yang telah dilakukan.. Rancangan Future State Value Stream Mapping (FSVSM).

\section{KESIMPULAN}

Kesimpulan yang dapat diambil berdasarkan penelitian tersebut adalah :

1. Dari hasil perhitungan Process Activity Mapping, pada proses produksi Syahla.01 Abaya di CV Sogan Batik Rejodani didapatkan hasil berupa Value Added Activity sebanyak 25 aktivitas dengan total waktu 13386.89 detik, Non - Value Added Activity sebanyak 21 aktivitas dengan total waktu 10688.00 detik, dan Necessary but Non - Value Added Activity sebanyak 13 aktivitas dengan total waktu 514.14 detik. Selanjutnya setelah dilakukan pengurangan aktivitas, didapatkan hasil berupa Value Added Activity sebanyak 25 aktivitas dengan total waktu 13386.89 detik, Non - Value Added Activity sebanyak 8 aktivitas dengan total waktu 2076.12 detik dan Necessary but Non - Value Added Activity sebanyak 12 aktivitas dengan total waktu 459.60 detik. Usulan perbaikan yang diberikan dapat mengurangi Non - Value Added Activity dari $43 \%$ menjadi $13 \%$. Dengan berkurangnya aktivitas tidak bernilai tambah, maka dapat meningkatkan output produk dalam sehari sehingga produktivitas sistem produksi meningkat.
2. Dari hasil membuat Current State Value Stream Mapping dan perhitungan Value Stream Analysis Tools selanjutnya dibuat usulan perbaikan menggunakan Future State Value Stream Mapping. Future State Value Stream Mapping disusun berdasarkan hasil pengurangan aktivitas pada process activity mapping. Didapatkan hasil berupa Future State Value Stream Mapping dengan menerapkan sistem kanban pada pembelian bahan baku. Selain itu diberikan usulan berupa pembelian mesin pengering yang dapat mengurangi waktu penjemuran menjadi lebih cepat. Usulan pembelian mesin jahit dan mesin pemotong supaya mengurangi tingkat cacat dan meningkatkan akurasi. Selanjutnya diberikan usulan berupa sinyal pelunasan untuk mempermudah stasiun kerja Packaging dan Shipping dalam melakukan pengiriman barang. Rancangan Future State Value Stream Mapping dapat mengurangi cycle time dari 16115.88 detik menjadi 15062.96 detik dan dapat mengurangi lead time dari 24589.028 detik menjadi 15932.62 detik. Pada awalnya perusahaan hanya mampu memproduksi 8 produk dalam sehari, dengan diterapkannya usulan yang diberikan dapat meningkatkan produksi menjadi 12 produk dalam sehari. Hal tersebut menunjukkan meningkatnya produktivitas sistem produksi CV Sogan Batik Rejodani. 


\section{DAFTAR PUSTAKA}

AR, R., \& al-Ahraf, M. Production Flow Analysis through Value Stream Mapping: A Lean Manufacturing Process Case Study. International Symposium on Robotics and Intelligent Sensors 2012 (hal. 1727). Malaysia: Elsevier, 2012.

Ayuningtyas, R., Setyanto, N. W., \& Efranto, R. Y. Analisis Peningkatan Produktivitas dan Efisiensi Kerja dengan Penerapan Kaizen (Studi Kasus pada PT Beiersdorf Indonesia PC Malang). 175-186.

Azizi, A., \& Manoharan, T. a. Designing a Future Value Stream Mapping to Reduce Lead Time using SMEDA Case Study. Procedia Manufacturing 2, 153-158, 2015.

Chaerul Saleh, \& Muhammad Ridwan Andi Purnomo. Metodologi Penelitian: Sebuah Petunjuk Praktis. Yogyakarta: Jaya Abadi Press, 2013.

Chen, L., \& Meng, B. The Application of Value Stream Mapping Based Lean Production System. International Journal of Business and Management, 203-209, 2010.

Choomlucksana, J., Ongsaranakorn, M., \& Suksabai, P. Improving the Productivity of Sheet Metal Stamping Subassembly. Procedia Manufacturing 2, 102107, 2015.

Daonil. Implementasi Lean Manufacturing untuk Eliminasi Waste pada Lini Produksi Machining Cast Wheel dengan Menggunakan Metode WAM dan VALSAT. Jakarta: Universitas Islam Indonesia, 2012.
Darti. (Agustus 10). Brainly. Diambil kembali dari http://brainly.co.id/tugas/314039 , 2014.

Firdaus, F. Konsep Lean Production. (D. K. Rizky, Pewawancara), 2016.

Gaspersz, V. Lean Six Sigma for Manufacturing and Service Industries. Jakarta: Gramedia Pustaka Utama, 2007.

Hines, P., \& Rich, N. The Seven Value Stream Mapping Tools. Lean Enterprise Research Centre, 1997.

Hines, P., \& Taylor, D. Going Lean. Cardiff: Cardiff Business School, 2000.

Imai, M. Gemba Kaizen: Pendekatan Akal Sehat, Berbiaya Rendah pada Manajemen. Jakarta: CV Teruna Grafica, 1998.

Intifada, G. S., \& Witantyo. Meminimasi Waste Menggunakan Value Stream Analysis Tool untuk Meningkatkan Efisensi Waktu Produksi. Jurnal Teknik Pomits Vol. 1, 1-6, 2012.

Kemnakertrans. Peningkatan dan Pengembangan Produktivitas, Melalui Green Productivity. Jakarta, Indonesia.

Kogel, I. W., \& Becker, d. i. Development of Design Support Tool for New Lean Production Systems. Procedia CIRP, 596-601, 2016.

Liker, J. K. The Toyota Way: 14 Prinsip Manajemen. Indonesia: Erlangga, 2006.

Matt, D., \& Rauch, E. Implementation of Lean Production in small sized Enterprises. 8th CIRP Conference on Intelligent Computation in Manufacturing Engineering (hal. 420). Elsevier, 2013. 
Monden, Y. Totoya Production System: an Integrated Approach to Just In Time. Boca Raton: CRC Press, 2011.

Nurhayati. Studi Perbandingan Metode Sampling Antara, 2008.

Ohno, T. Toyota Production System. Cambridge: Productivity Press, 1988.

Purba, H. H. Diagram Fishbone dari Ishikawa, 2008.

Rohac, T., \& Januska, M. Value Stream Mapping Demonstration on Real Case Study. Procedia Engineering 100, 520-529, 2015.

Rohani, J. M., \& Zahraee, S. M. Production Line Analysis via Value Stream mapping: a Lean Manufacturing Process of Color Industry. Procedia Manufacturing 2, 6-10, 2015.

Roother, M., \& Shook, J. Learning to See: Value Stream Mapping to Create Value and Eliminate Muda: Version 1.3. Lean Enterprise Institute, 2003.

Sa'udah, N., Amit, N., \& Ali, M. N. Facility Layout for SME Food Industry via Value Stream Mapping and Simulation. Procedia Economic and Finance 31, 797-802, 2015.

Sastrowinoto, S. Meningkatkan Produktivitas dengan Ergonomi. Jakarta: PT Pustaka Binaman Pressindo, 1985.

Setiadi. Konsep \& Penulisan Dokumentasi Asuhan Keperawatan Teori dan Praktik. Yogyakarta: Graha Ilmu, 2012.

Sogan Batik. Data Permintaan Produk, 2016.

Syarif, R. Produktivitas. Bandung: Angkasa Bandung, 1991.
Tague, N. R. The quality toolbox. (2th ed.). Milwaukee, Wisconsin: ASQ Quality Press, 2005.

Tilak, Minakshi, Aken, E. V., McDonald, T., \& Kannan, R. Value Stream Mapping: A Review and Comparative Analysis of Recent Applications, 2010.

Toivonen, T., \& Siitonen, J. Value Stream Analysis for Complex Processes and Systems. Procedia CIRP 39, 9-15, 2016.

Tyagi, S., Choudhary, A., Cai, X., \& Yang, K. Value Stream Mapping To Reduce The Lead - Time of A Product. International Journal of Production Economics, 202-212, 2015.

Venkataraman, K., Ramnath, B., Kumar, V., \& C.Elanchezhian. Application of Value Stream Mapping for Reduction of Cycle Time in a Machining Process. 3rd International Conference on Materials Processing and Characterisation, 1187-1196, 2014.

Wee, H. M., \& Wu, S. Lean Supply Chain and its Effect on Product Cost and Quality: a Case Study on Ford Motor Company. Supply Chain Management : an International Journal, 335-341, 2009.

Yadav, R., Shastri, A., \& Rathore, M. Increasing Productivity by Reducing Manufacturing Lead Time through Value Stream Mapping. International Journal of Mechanical and Industrial Engineering, 2012. 


\section{LAMPIRAN}

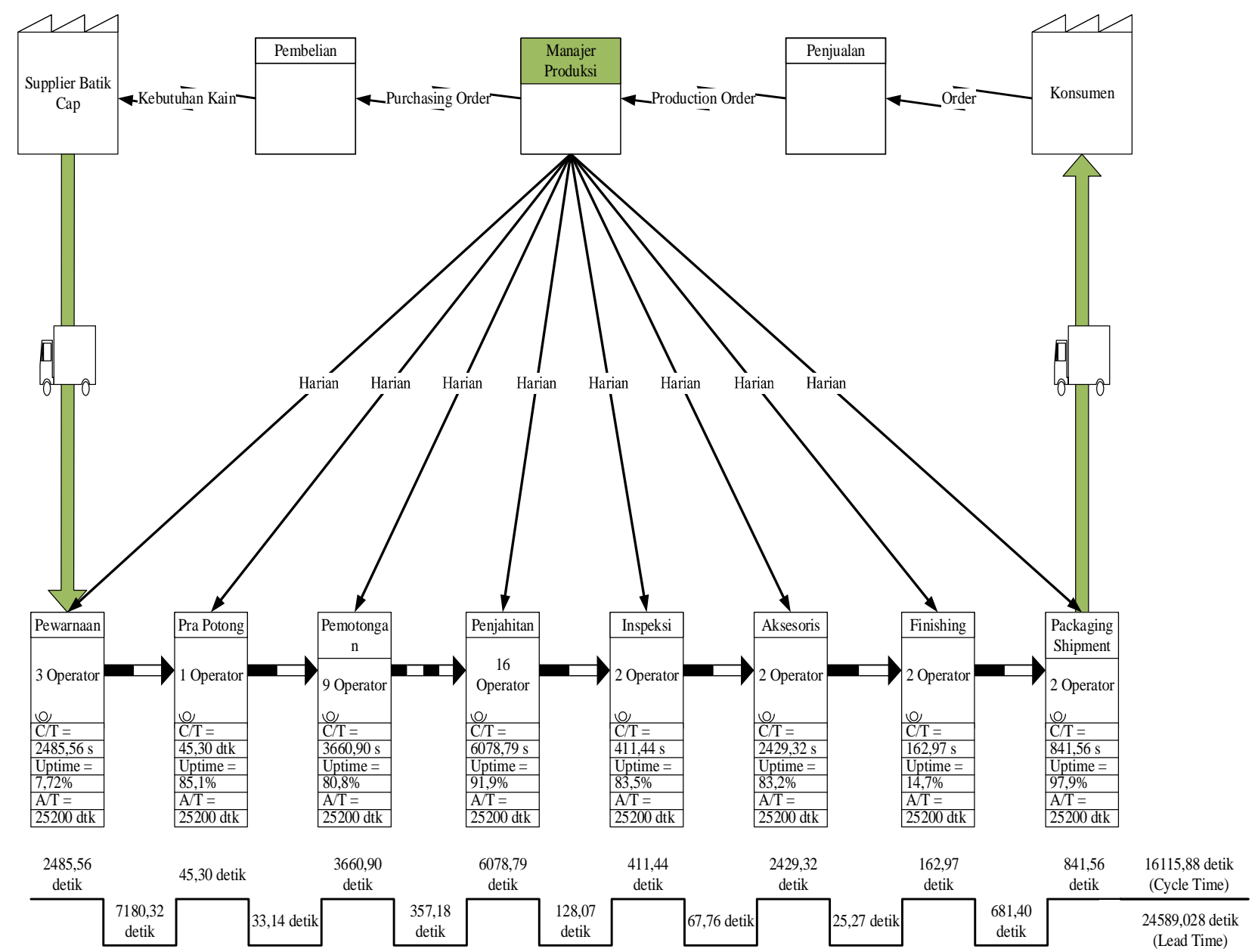

Tabel 8 Perhitungan VALSAT

\begin{tabular}{|c|c|c|c|c|c|c|c|c|c|}
\hline \multirow[b]{2}{*}{ No } & \multirow[b]{2}{*}{ Pemborosan } & \multirow{2}{*}{$\begin{array}{c}\text { Perhitungan } \\
\text { Skor }\end{array}$} & \multicolumn{7}{|c|}{ Detailed Mapping Tools } \\
\hline & & & PAM & $\begin{array}{c}\text { SCR } \\
M\end{array}$ & PVF & QFM & DAM & DPA & PS \\
\hline 1 & Overproduction & 0 & 0 & 0 & & 0 & 0 & 0 & \\
\hline 2 & Defect & 3 & 3 & & & 27 & & & \\
\hline 3 & $\begin{array}{l}\text { Unnecessary } \\
\text { Inventory }\end{array}$ & 0 & 0 & 0 & 0 & & 0 & 0 & 0 \\
\hline 4 & $\begin{array}{l}\text { Inapproriate } \\
\text { Processing }\end{array}$ & 2 & 18 & & 6 & 2 & & 2 & \\
\hline 5 & $\begin{array}{l}\text { Excessive } \\
\text { Transportation }\end{array}$ & 1 & 9 & & & & & & 1 \\
\hline 6 & Waiting & 2 & 18 & 18 & 2 & & 6 & 6 & \\
\hline 7 & $\begin{array}{l}\text { Unnecessary } \\
\text { Motion }\end{array}$ & 2 & 18 & 2 & & & & & \\
\hline & Total & 10 & 66 & 20 & 8 & 29 & 6 & 8 & 1 \\
\hline & Ranking & & 1 & 3 & 4 & 2 & 6 & 4 & 7 \\
\hline
\end{tabular}

